\title{
Normas para apresentação de trabalhos
}

A revista outra travessia aceita trabalhos inéditos voltados para a literatura, a teoria literária e outras artes, redigidos em português ou castelhano. A submissão dos textos deve seguir as chamadas de publicação lançadas duas vezes ao ano.

Os trabalhos serão submetidos ao conselho de pareceristas da revista após breve análise da pertinência ao tema proposto e às normas de publicação. Sugestões de modificação ou revisão por parte do conselho consultivo serão comunicadas aos autores.

Os trabalhos devem ser enviados através de cadastramento na plataforma de periódicos www.periodicos.ufsc.br/index. php/Outra/index ou pelo email outratravessia@gmail.com

O original deve ser apresentado em página A4 na seguinte sequência, com fonte Garamond:

Título do trabalho: centralizado, tamanho 14, espaçamento 1,5 .

Subtítulos (quando houver): recuo de $1 \mathrm{~cm}$, em negrito, tamanho 12, espaçamento 1,5 .

Nome do autor: Tamanho 12, alinhado à direita, espaçamento 1,5 .

Instituição: embaixo do nome, sem a utilização de parêntese. Para universidades brasileiras, utilizar as siglas (ex: UFSC; UNB), para universidades estrangeiras ou outras instituições, colocar o nome por extenso e o país (ex: Universidade de Buenos Aires - Argentina). 
Resumo: Em português, tamanho 11, justificado, espaçamento 1,5. O resumo deve ter entre 100 a 200 palavras. Embaixo, sem separação de linha nem negrito: Palavras-chave: entre 3 e 5, separadas por ponto-e-vírgula.

Abstract, Resumé ou Riassunto: Em inglês, francês ou italiano, tamanho 11, justificado, espaçamento 1,5. O Abstract, Resumé ou Riassunto deve ser a versão traduzida do resumo em português. Embaixo, sem separação de linha nem negrito: Keywords, Mots-clés ou Parole chiavi: entre 3 e 5, separadas por ponto-e-vírgula.

Epígrafes (quando houver): tamanho 12, itálico, alinhado à direita, com o autor da citação embaixo, sem itálico, espaçamento 1 .

Texto: Fonte Garamond, Tamanho 12, espaçamento 1,5, justificado, com recuo de $1 \mathrm{~cm}$ para início de parágrafo. $O$ texto não deve exceder as 20 páginas, sem incluir as páginas de referências bibliográficas. As páginas não devem ser numeradas.

Referências no corpo do artigo: devem ser apresentadas em nota de rodapé. Importante: não aceitaremos o sistema de citação autor: data. Em caso de referências recorrentes deve-SE repetir o título e o ano de uma obra já citada, evitando o uso de op.cit. Utilizar Ibidem, apenas em caso de repetição imediatamente posterior de citação da mesma obra. Utilizar Idem, no caso citação imediatamente posterior de outra obra do mesmo autor. Exemplos:

LIMA, Luiz Costa. A lâmina assimétrica ou o elogio da agudeza. In: Escritos de véspera, 2011, p.38. Ibidem, p. 49.

AGAMBEN, Giorgio. Profanações, 2007, p. 77. Idem, A linguagem e a morte, 2009, p. 83.

Quando se tratar de uma citação presente num outro suporte utilizar apud., sem necessidade de utilizar caixa alta. Exemplo:

Ana Cristina Cesar, apud. SÜSSEKIND, Flora. Até segunda ordem não me risque nada, 2007, p. 52. 
Citações com 4 ou mais linhas: devem ser separadas do texto por duas linhas, com recuo de 4 centímetros, fonte 10 , espaçamento simples. Citações em castelhano, francês, inglês ou italiano podem ser mantidas no idioma original. Para outros idiomas, o autor deve colocar uma nota de rodapé com uma versão do idioma do artigo.

Ilustrações (quando houver): devem ser designadas como figuras, numeradas no texto (fig. 01, fig. 02) com título ou legenda abaixo da mesma.

Referências: Tamanho 11, alinhadas à esquerda, espaçamento simples, com uma linha de espaço entre uma referência e outra. A apresentação das referências deve respeitar o padrão ABNT. Exemplos:

BENJAMIN, Walter. A modernidade e os modernos. Trad. Heindrun Krieger; Arlete de Brito e Tania Jatoba. $2^{\circ}$ ed. Rio de Janeiro: Tempo Brasileiro, 2000.

AGAMBEN, Giorgio. O que é o dispositivo? In: revista outra travessia, n. 05. Trad. Nilcéia Valdati. Florianópolis, 2005, p. 09-16. Disponível em: www.periodicos.ufsc.br/index.php/ Outra/article/ view/12576/11743

LUDMER, Josefina. La novia (carta) robada (a Faulkner) [sem data/ ou data fornecida no site]. Disponível em: www.cartas. org.ar/lecturas/lec-lud-lan.html Acesso em 12/02/2013

Os autores terão direito a 2 exemplares da revista. 
